\title{
The Impact of the Department of Public Relations and Media on Crisis Management: Case Study of the Greater Salt Municipality, Jordan
}

\author{
Mohammed A. Abu Rumman ${ }^{1 *}$ and Amani Abdelhafeeth Alzeyadat ${ }^{2}$ \\ 'Department of Business Administration, Faculty of Business, Al-Balqa' Applied University, Jordan \\ ${ }^{2}$ Independent Scholar, Jordan
}

\begin{abstract}
Greater Salt Municipality is a vital sector in Jordan that deal with crises to compel them directly to deal with media and public opinion and requires adopting the modern administrative methods to take preventive provisions or predict the crisis's occurrence before it happens. Thus, the present study planned to clarify the Public Relations and Media Department's impact on the Greater Salt Municipality's crisis management. The researchers developed a questionnaire to collect data from selected study populations. Thus, both the retrieved and valid questionnaires for analyses (130) out of (135) copies distributed to the study sample utilized as the simple random sampling to collect data. Further, the researchers had used arithmetic means, percentages, simple regression standard deviation, frequencies, and multiple regressions to attain the outcome. The study reached the conclusions with the important result that statistically significant, which may help the Department of Public Relations and media on Crisis Management in Greater Salt Municipality.
\end{abstract}

Keywords: Public Relations Department, Media, Crisis Management, Greater Salt Municipality

\section{Introduction}

Municipalities constitute one of the most important sectors in Jordan, whose work nature depends on dealing with crises, which compels them to deal directly with media and public opinion. The municipality's response to confronting crises and preparing for them requires adopting modern administrative methods to take preventive provisions or predict the crisis's occurrence before it happens. If it occurs, organizational units should be prepared and trained to manage and remove their effects. Hence, the municipality preserves its positive image in the minds of the public.

Public relations are the main organizational member of any organization whose functions are linked to communicate with the media and the public. It is the first organizational unit that faces and responds to crises. Consequently, it adopts a communication and media plan to mitigate the impact of crises when occurring and control the communication channels to ensure the flow of information to the internal and external audiences to address any adverse effects incurred by crises.

The crisisis unpredictable(Fall,2004)and can potentially lead to disaster with mega-scale organizational damage if not appropriately managed (Sawalha, et al., 2013). Crisis ranges from economic, psychopathic, and natural calamities (Abu-Tayeh, \& Mustafa, 2018). Putting an efficient crisis management function in place leads to protecting the organization and preventing the adverse impact on these organizations' core business (Ibid). Media and public relations departments in a given 
organization become necessary; the media serves as a channel for disseminating information and updating the public through a one-to-many communication channel (APFM, 2015). Diagnosis of a crisis should consider the difficulty in gathering data, in particular when political instability prevails. Therefore, the role of medial becomes vital as they provide real-time information and updates. As such, the media's role becomes significant for creating mass awareness to ensure active public participation (Masoumi, G., \& Noyani, A., 2019).

Furthermore, building partnerships helps any organization respond to crises and partnerships with large business enterprises to analyze and investigate the crisis (Ibid). The media department must communicate reliable information to the public and increase their awareness of the hostile conditions to control their reactions towards the crises. For that reason, the information could be obtained from official and formal sources before reporting them to the public. Then, mimic the local communities' anxiety and panic (Ghassabi, \& Zare, 2015). Public reporting must be well constructed and designed to be objective, honest, and speedy to retain the trust and confidence in the organizations (Das, 2009). Appealing and desirable messages to the public were found to be a smart way of controlling panic. The media department should verify and summarize many relevant facts and incorporate them into public reports to engage and entertain the audience (Ibid).

Reporters should adhere to their job objectives and avoid influencing the audience (Klepka, 2019; Hosseini, 2019). The Public Relations (PR) department is accountable for any organization to the stakeholders and public and should employee tool to maintain the organizational reputation (Smith, 2007; Anand, \& Hosseini, 2016). PR departments assist in problemsolving and developing an effective decision-making process (Mat et al., 2017). The public relations department also fosters organizational changes by strengthening stakeholder relationships and positively influencing the community (Al-Jenaibi, 2015).

To summarize, the public relations department should focus on diagnosing the current situation, establishing a crisis management team, streamlining organizational facilities, and reporting to the public, including responding to inquiries to build goodwill (Smith, 2007; $\mathrm{MH}$, et al., 2019). Effective communication (Alzahrani, 2016), transparent and professional (Al-Jenaibi, 2015) empowers any organization to influence stakeholder's perception through the public relations departments and infuse loyalty through strategic brand-building practices (Fall, 2004).

Hence, this study sought to determine the Public Relations Department and Media's impact on the Greater Salt Municipality crisis management. Environmental changes in the organization's environment, whether internal or external, lead to business organizations' crises (Hosseini \& Farooq, 2019). The public relations department's importance emerges from rebalancing the organization as an entity and preserving it by finding communication lines between the organization and its clients and using appropriate media (Al-Hassoun, 2012). It also creates a positive climate to deal with crises and improve its mental image among its audience (Jafar, 2009). Organizations that cannot manage effective public relations and media plans make it difficult for them to manage the crises they face (Al-Jarallah, 2010). Consequently, the study problem lies in the main subsequent question: What are the Department of Public Relations and media impact on crisis management in Greater Salt Municipality.

From this main question, a set of sub-questions emerge that answered through the theoretical and practical content of this study:

1. What is the reality of the Department of Public Relations on crisis management in the Greater Salt Municipality?

2. What is the reality of the media on crisis management in the Greater Salt Municipality?

\section{Significance of the Study}

1. The study's significance emerges through the importance of the Department of Public Relations' role in creating the appropriate conditions for senior management to assist it in crisis management (Al-Qahtani, 2004). 
2. The study's importance also lies in the permanent need to be prepared to deal with crises and disasters due to their destructive effects and their great repercussions on the local community and to preserve the humans and their survival (Al-Naji, 2012; Hosseini \& Farooq, 2019).

3. Media has a vital role in facing crises and disasters, and in identifying the positive effects of media planning that precedes the occurrence of crises and disasters, which contributes to mitigating the effects of those crises, and the importance of providing the public by way of information along with facts to assist them in confronting with and dealing with crises and accidents

4. Providing a set of conclusions and recommendations that benefit decision-makers, researchers, and those interested in this topic.

\section{Objectives of the Study}

Present research mainly explains the Department of Public Relations and media impact on Greater Salt Municipality's crisis management. The study has a secondary objective that can be summarized as follows:

1. Demonstrating the tasks and functions that rest on the Public Relations Department's shoulders to confront crises in Greater Salt Municipality.

2. Highlighting the role played by the Public Relations Department in reducing the impact of crises in Greater Salt Municipality.

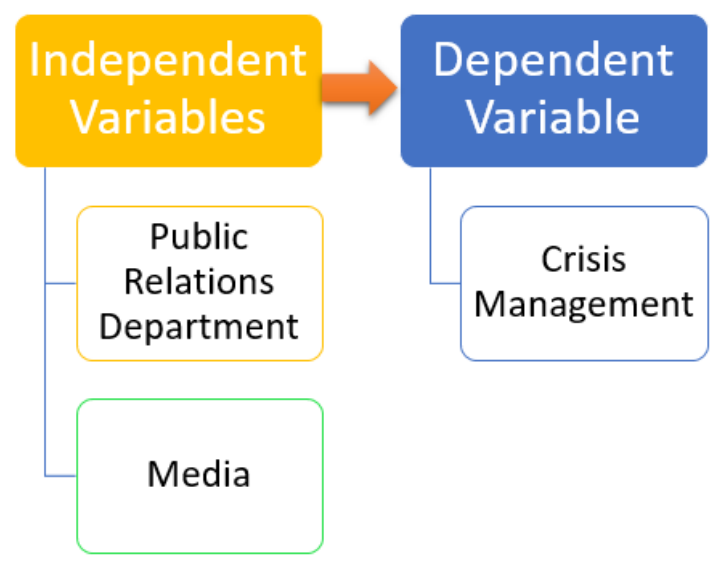

Figure 1. Study model.

Source: Researchers based on previous studies of (Al-Saeedi, 2013; Al-Naji, 2012; Al-Qahtani, 2004).
3. Identifying the impact of the media's role on crisis management in Greater Salt Municipality.

4. Providing a set of conclusions and recommendations for the Public Relations and Media in Greater Salt Municipality, which contribute to enhancing its contribution to facing crises.

\section{Variables}

The study model contains the two independent variables: Public Relations and Media Department, and the dependent variable: Crisis Management in Greater Salt Municipality.

\section{Study Hypotheses}

Base on the above, the following hypotheses are formulated:

H01: Public Relation Department has no statistically significant impact on Crisis Management in Greater Salt Municipality at $(\alpha \leq 0.05)$

H02: Media has no statistically significant impact on Crisis Management in Greater Salt Municipality at $(\alpha \leq 0.05)$

\section{Theoretical framework}

\subsection{Previous Studies}

\subsubsection{Arabic Studies}

Almahraj (2017) Study entitled "The profession of public relations in Saudi Arabia: A socio-cultural perspective" This study aimed to identify the reality of Public Relations Department the Public Sector Corporations in the Saudi Arabia Kingdom and their role in dealing crisis at all its stages. The researchers have selected a simple random sample consisted of 66 companies in the city of Riyadh. The researcher has used a questionnaire directed to the Public Relations Department officials in these companies. The study revealed a decrease in dependence on public relations and their participation in crisis management among the sample companies that had previously gone through a crisis. The study results have indicated a centrality in these companies represented by the higher 
management's acquisition of the largest percentage of participation in crisis management. Also, it stated that the Department of Public Relations scarcely performed studies and research in the pre-crisis phase. Moreover, results of the study revealed the lack of interest of the sample companies in qualifying and training their employees in the ground of crises, in addition to the scarcity of affiliating public relations employees with activities related to the same field and the majority of the study sample adopted wrong methods in dealing with the media when crises occurred.

Ghassabi, F.,\& Zare, F. F. (2015). made out that media planning positive effects in crises and disasters by preparing effective media plans that support resistance operations and remove their negative effects and studying crises, along with disasters to develop strategies to ensure the effectiveness of facing them. Besides, identifying the media role planning in the crisis and disasters, can limit negative impacts resulting from the lack of plans to organize and manage crises and disasters. The descriptive-analytical method used. The questionnaire used as a data collection tool (Ghassabi \& Zare, 2015).

Moreover, the study population consisted of 362 employees in the Civil Defense Directorate, and 208 workers in the Ministry of Culture and media. The researchers have chosen a random sample of $(40 \%)$ of the employees of the Civil Defense Directorate $(40 \%)$ of the workers in the Ministry of Culture and media. Thus the total number of the sample individuals equals (228). However, the study found that the media plans prepared by the Department of Public Relations of Civil Defense Directorate are critical to face crises and disasters. Besides, success requires civil defence experts who are competent and able to limit the effects of these crises, include civil defense instructions, and educate citizens about security and safety measures. The study also found that the Department of Public Relations of Civil Defense Directorate realizes the importance of resorting to media to face crises and disasters. Besides, the study sample individuals have similar visions towards the role of media planning in crises and disasters facing, regardless of age, qualifications, or experience.
Furthermore, Farooq \& Dinney (2009) aimed to identify the General Directorate of Civil Defense's public relations department's role in Riyadh to deal with crises and disasters. A questionnaire was designed and distributed to all (41) employees of the Public Relations Department. The most important results of the study were the lack of formal systems that define the role of public relations management in crises and disasters, lack of technical, organizational, and material capabilities in managing public relations needed in the crisis and disaster management process. Moreover, the study concluded that some problems and obstacles limit public relations management's efficiency in facing crises and disasters, including the lack of databases and information in crisis along with disaster management field. In addition to, lack of specifying duties and responsibilities, lack of trained human competencies, and scarcity of scientific methods and operations research to deal with the crisis or disaster stages.

\subsubsection{English Studies}

Holly M. H. (2008) in his study on "Crisis Management in Higher Education: What Have We Learned From Virginia Tech?" refer to the study of Relle (1998) that aimed to clarify the effectiveness of Crisis Management; the study included 71 members of 35 commercial banks' executives. The study indicated that the crisis elements such as sensing the problem, diagnosis, response decisions, inflow, and outflow of information required managing effectively. The study explained that the most important features are rapid reactions, the ability to make decisions in due time, previous experience, excellent management, communications, and customer relationships. Furthermore, the study confirmed that poor communications are the most significant obstacles and cannot deal with media (Holly, 2008).

Christine \& Mitroff (1993) study aimed to identify the functions and activities of public relations and which are more critical in making decisions and activities. The research survey included 1000 major American companies. The study results emphasized the importance of information systems and public relations and identified activities that must be shared in the team, which has the most significant impact on public relations management operations regarding human and financial resources.

SDMIMD Journal of Management | Print ISSN: 0976-0652 | Online ISSN: 2320-7906 


\subsection{Theoretical Background}

\subsubsection{Public Relations Department}

Public relations are one of the current administrative jobs that emerged in technological and scientific development in modern times. It becomes a necessity for every organization that engages directly or indirectly affecting the public; thus, public relations work in two directions; on the one hand, it secures the relationship with its internal employees, and on the other hand, it takes care of the relationships with the external publics that benefits from participates in the services (Al-Rubaie, 2010).

Public Relations defined as: "This profession that concerned with the building of organization's reputation through the planned effort that seeks to build continuous relations with the masses and gain support for the administrative work in addition to the influence opinions and behaviors of the masses to achieve a common understanding between the organization and the masses (Al-Saeedi, 2013).

Al-Shami (2009) commented on the goals of public relations and functions as revolving around the increase of the public's interest in organizations' affairs through explanation of general purposes that trends to information about public affairs contemporary and problems in addition to organizational plans and goals development (Jamal et al., 2017; Daraghmeh, 2011). Moreover, clarified the achievement responsibilities, supported cooperation between the organization and similarities related to business links, which strengthens the relationship with media, advertising agencies, magazines, and newspapers as well as following up on the complaints, criticisms, and suggestions about organizations preparation and receive the delegations to organize to show the in a decent organizational level (Ibid). Public Relations Department function involves in newsletters translation and research for media archive, follow up on agreements and activities in an accessible manner, supervise the establishment of exhibitions and conferences, support of ion of the relationship between employer and employee and conduction of celebrations in coordination with the relevant authorities (Ibid).
Al-Lawzi (2010) believes that public relations are based on a set of principles, influenced by a group of factors; the principles on which mainly based the quality of work, social responsibility, respect of opinions, commitment to good morals, adoption of scientific methodology, and attention to elements of the internal environment. However, the factors affected by it are economic, political, social, and religious factors as external factors and top management's view of public relations management, recruitment and selection policies, media policies, and material and human factors as internal factors.

\subsubsection{Media}

Successful organizations pay great attention to the media, as it is the language of the modern age, and it is one of the aspects of communication with the external community, divided into two parts: news media representing communication with the community and interested in publishing news of the organization, achievements, and meetings. Nevertheless, advertising media aims to draw a positive mental image in the audience's minds to interact with the organization and support it morally. Media takes various means, including; newspapers, broadcasts, satellite channels, websites, periodicals, magazines and publications, paper advertising and suspended advertising, mini ads, visual ads, and advertising in Bills of companies in different establishments (Al-Dulaimi, 2011).

\subsubsection{Crisis Management}

The science of crisis management has expanded to become a method used by most institutions and organizations to solve emergency predicaments. Thus crisis management is defined the same as a necessary procedure to contract with an unusual situation in the direction of damage minimization as well as losses to avoid the disturbances (Al-Sawafi, 2018; Al-Bazzaz, 2001; Christophe, 2007).

There are many reasons for the emergence of crises due to different types and fields, due to the external environment some are outside the man's capabilities, some related to the internal environment, while the others are social or administrative reasons due to the individual (Al-Muhammadi, 2018; Hawamdeh, 2003). 
Crisis management passes through several stages; the first stage is to avoid and ignore the crisis because top management believes it is under control. Concealment may have a role in avoiding some crises. The second stage includes preparing to manage the crisis by setting plans to address the crisis, such as communications and establishing public relations plans. The third stage is characterized by acknowledging the crisis's existence, which requires specialists from inside and outside the organization to understand the situation. The fourth stage is based on crisis containment; this stage depends on providing the necessary information and benefiting from it. This stage is concerned with implementing a confrontation plan to reduce the damages caused by the crisis, while the fifth stage is based on settling the crisis, and here speed plays a critical and role. The last stage revolves around benefiting from the crisis; this stage includes attempts to compensate for some of the losses resulting from the crisis and help from accumulating experiences in the reform and development process (Zidan, 2003).

Fazli \& Farooq (2018) stated that the organization should respond to crises according to their type and nature. Many strategies could be adopted, such as Change Course Strategy, a strategy based on transforming the crisis into another area or something productive and effective. Moreover, the Crisis Fragmentation Strategy; which based on full knowledge of all the factors details causing the crisis through the identification of conflicting layers and potential benefits and then dividing the impact of the crisis into multiple resolvable parts. Crisis Containment Strategy is based on confining the crisis to a limited scope and freezing it at every stage that can be excluded and lost its strength. Crisis Evacuation Strategy; is a strategy based on trying to end the crisis by identifying the content and causes of the crisis. Tactical Reserve Strategy; it depends on the availability of a safe stock of production requirements reported when the organization is exposed to a crisis characterized by a lack of production requirements.

\subsubsection{The Impact of the Department of Public Relations and Media on Crisis Management}

The Public Relations Department is the leading member that should be involved in crisis management.
The success of this participation depends on several aspects, most of which relate to the strategy and culture of the company is planning for crisis management, the extent of its interest in communication with its audience and the development of public relations practices and its vision in engaging practitioners when planning for crisis management (Al-Jarallah, 2010; Arpan, \& Pompper, 2003; Qwaider, et al., 2019).

It is the responsibility of public relations, media, and moral guidance to address crises with a set of necessary measures and communications with the internal and external audiences of the organization and to create a festive atmosphere for positive interaction with the secretions of the crisis to enhance the organization's reputation and to preserve its mental image. The media are among the most accurate and sophisticated techniques in facing challenges and crises during and after the crisis until the media become an essential part of modern science in crisis management. Organizations can no longer turn their backs on the media and its means (Jafar, 2009).

Ahmed (2018) mentioned that effective management of crisis communication requires the public relations agency to carry out multi-disciplinary, continuous, and communicative tasks. It is divided into first, precrisis communications that include management communications change; case management communications that cover planning tasks. Secondly, communications during the crisis related to the public relations agency's technical and executive tasks transform the predetermined plan for preparation into an execution plan in which messages and communication are used to address the identified crisis. Finally, postcrisis communications relate to the evaluation of tasks in which strengths and weaknesses are studied and lessons drew to utilize the public relations future work.

A plan could be devised to achieve effective communication with the crisis; that includes the procedures which could take to instill a sense of reassurance among citizens, the type of information could be given to assist in facing the crisis, and the information that may be published or broadcasted to the public opinion. Also, training media professionals could play a role and communicate the right information 
promptly. The plan may include finding the alternative means of communication to inform the public that if due to the defect, which may crisis cause in the traditional means of communication, they cannot contact.

\section{Study Methodology}

\subsection{The Study Population along with Sample}

A set of 135 copies of the question was distributed to the greater Salt Municipality's employees at different administrative levels. From the restored documents, only 130 valid copies were collected for analysis with a percentage of $96 \%$ and considered a high rate. Moreover, the study sample considers a simple random type where the researcher considered that the sample individuals could accurately represent the study population.

\subsection{Data Collection}

a. Secondary sources: related to the theoretical and scientific aspect of the study subject, including books, periodical journals, and research articles.

b. Primary sources, including designed a questionnaire and distribution to the study sample to collect data from the target group.

\subsection{Study Instrument}

A questionnaire designed to suit the objectives of the study through the utilization of literature, which consisted of two parts:

a. The first part: consisted of the demographic variables, including gender, years of experience, marital status, educational qualification, and age of the study population.

The second part: consisted of three axes. Each axis includes a set of questions. The axis included questions about public relations management, the second axis included questions about the media, and the third axis had questions on crisis management. A five-point Likert scale was used to demonstrate the individual's opinions within the study sample. The questionnaire was presented to a group of specialists and workers in the same field to arbitrate that who indicate its suitability for the study purposes, moreover, according to the opinions of the arbitrators' suitable amendments made to the designed questionnaire. Besides, appropriate statistical methods such as mean, standard deviation, Correlation coefficient, and other tests were used in SPSS statistical package to analyze the data collected.

\subsection{Validity and Reliability}

Validity is the extent to the instrument that measures what could perform and measure (Sekaran, 2003). The validity of the questionnaire estimated through the use of Cronbach's Alpha coefficients, as mentioned in Table 1.

Table 1. Alpha Cronbach's Test

\begin{tabular}{|l|c|c|}
\hline Field & No. of Items & $\alpha$ Factor \\
\hline Public Relations Department \& Media & $1-20$ & $84.8 \%$ \\
\hline Crisis Management & $20-33$ & $71.6 \%$ \\
\hline An instrument as a Whole & $1-33$ & $85.5 \%$ \\
\hline
\end{tabular}

Source: Researchers

Table 1 shows that Alpha Cronbach's coefficient of all main elements of the questionnaire enjoys a great degree of reliability. Henceforth, the researchers have ascertained the validity and reliability of the questionnaire.

\section{Analysis}

\subsection{Descriptive Statistical Methods}

\subsubsection{Gender}

Table 2 illustrates the number of Male and Female individuals in the study population.

It is evident from table 2 that in the study population, the number of male individuals equals 79 with a percentage of $60.7 \%$, while the number of female individuals equals 51 with a rate of $39.3 \%$.

Table 2. Distribution of the individuals of the study sample according to gender

\begin{tabular}{|l|c|c|}
\hline Gender & No of Respondents & Percentage \\
\hline Male & 79 & $60.7 \%$ \\
\hline Female & 51 & $39.3 \%$ \\
\hline Total & 130 & $100 \%$ \\
\hline
\end{tabular}

Source: Researchers 


\subsubsection{Scientific Qualification}

Table 3 illustrates the distribution of the individuals of the study sample according to scientific qualification. It demonstrates that employees with a bachelor's degree equal to 82 employees and form the highest percentage of $63.0 \%$ while employees held higher diploma degrees equal to 19 employees with a rate of $14.6 \%$. In the third rank, employees holding a master's degree are equaled 15 , with a rate of $11.5 \%$. And employees with a Ph.D. degree equal to 4 with a percentage of $3.0 \%$. Finally, employees with a Secondary certificate or less equal to 10 with a rate of $7.6 \%$.

Table 3. Distribution of the individuals of the Study Sample according to Scientific Qualifications

\begin{tabular}{|l|c|c|}
\hline Scientific Qualification & Sum & Percentage \\
\hline PhD & 4 & $3.0 \%$ \\
\hline Master & 15 & $11.5 \%$ \\
\hline Bachelor & 82 & $63.0 \%$ \\
\hline Higher Diploma & 19 & $14.6 \%$ \\
\hline Secondary certificate or less & 10 & $7.6 \%$ \\
\hline Total & 130 & $100 \%$ \\
\hline
\end{tabular}

Source: Researchers

\subsubsection{Years of Experience}

Table 4 shows that $36.9 \%$ of the study population have less than or equal to 5 years of experience, followed by $33.8 \%$ of those with 5 to 10 years of experience, then $29.2 \%$ of those with 10 years and more municipal expertise.

Table 4. Distribution of the individuals of the Study Sample according to Years of Experience

\begin{tabular}{|l|c|c|}
\hline Years of Experience & Sum & Percentage \\
\hline$\leq 5$ years & 48 & $36.9 \%$ \\
\hline $5-10$ years & 44 & $33.8 \%$ \\
\hline 10 years or more & 38 & $29.2 \%$ \\
\hline Total & 130 & $100 \%$ \\
\hline
\end{tabular}

Source: Researchers

\subsubsection{Marital Status}

Table 5 shows the marital status of individuals in the study population. It demonstrates that a large percentage of married individuals of the study sample counted to 83 and make up $63.8 \%$ of the total study population,
Table 5. Distribution of the individuals of the Study Sample according to Marital Status

\begin{tabular}{|l|c|c|}
\hline Marital Status & Count & Percentage \\
\hline Single & 32 & $24.6 \%$ \\
\hline Married & 83 & $63.8 \%$ \\
\hline Widow & 10 & $7.6 \%$ \\
\hline Divorced & 5 & $4 \%$ \\
\hline Total & 130 & $100 \%$ \\
\hline
\end{tabular}

Source: Researchers

followed by the singles group of 32 with $24.6 \%$ of the entire study population. The lowest number belongs to the divorced group of 5 , and they make up $4 \%$ of the total study population.

\subsubsection{Age}

Table 6 illustrates that $34.61 \%$ of the study population belong to the age group between 35 to 45 years old count to 45 employees. Moreover, 35 employees in the age group of 45 years old or more formed a rate of $26.92 \%$. In the last rank, employees whose age is less than 20 years old create a rate of $13.07 \%$.

Table 6. The Distribution of the individuals of the Study Sample according to age

\begin{tabular}{|l|c|c|}
\hline Age & Count & Percentage \\
\hline$<20$ Years & 17 & $13.07 \%$ \\
\hline 20 to $<35$ Years & 33 & $25.4 \%$ \\
\hline 35 to 45 Years & 45 & $34.61 \%$ \\
\hline$\geq 45$ Years & 35 & $26.92 \%$ \\
\hline Total & 130 & $100 \%$ \\
\hline
\end{tabular}

Source: Researchers

\section{Hypotheses Testing}

The arithmetic mean and standard deviation calculated for the respondent's answers as follows:

A Likert 5-point scale used according to the following weight scale:

5 for strongly agree

4 for agree

3 for neutral

2 for disagree

1 for strongly disagree 
The following criteria adopted for study items analysis:

1. (1-2.33) low importance

2. (2.34-3.67) moderate importance

3. (3.68-5.00) high importance

Table 7 illustrates respondents' perceptions according to the importance of the Public Relations Department in arithmetic mean. Standard deviation through items (1-10) of the questionnaire indicated that the respondents' arithmetic means about their perception of the Public Relations Department equals 4.478 with a standard deviation of 0.65 as a high degree. It should be noticed that this mean is very close to the upper limit of the adopted scale of the study.

Table 8 illustrates respondents' perceptions according to the importance of media in terms of arithmetic mean and standard deviation through items (1-10) of the questionnaire. It indicates that the arithmetic mean of the respondents' answers about the Public Relations Department's perception equals 4.273 with a standard deviation of 0.765 that is of high degree and should be noticed that mean is exceptionally close to the adopted scale of the study's upper limit.

Table 9 illustrates respondents' perceptions according to the importance of Crisis Management in terms of the arithmetic mean. Standard deviation through items (1-10) of the questionnaire indicates that the arithmetic means of the respondents' answers about their perception in the Public Relations Department equal to 4.341 with a standard deviation of 0.645 as the high degree. It should be noticed that this mean exceptionally is close to the adopted scale's upper limit of the study.

\subsection{First Hypothesis}

H01: Public Relation Department has no statistically significant impact on Crisis Management in Greater Salt Municipality $(\propto \leq 0.05)$.

To test the hypothesis, simple linear regression was used, and the results of this test shown in Table 10 .

The frequency value of 40.911 is statistically significant value, which indicates that the null hypothesis rejected, moreover the alternative hypothesis accepted, and this means that the Public Relations Department has a statistically significant impact on crisis management in the Greater Municipality of Salt and reinforced by the explanatory value of $\mathrm{R}^{2}$ that equals to 0.158 . Thus, the result is consistent with the findings of Fazli \& Farooq (2018).

Table 7. Arithmetic Means and Standard Deviations the questionnaire Items related to Public Relation Department discerningly ordered according to their importance

\begin{tabular}{|l|l|c|c|c|}
\hline No. & Items & Mean & S.D. & Importance \\
\hline 1 & The Public Relations Department develops training programs & 4.600 & 0.558 & High \\
\hline 5 & $\begin{array}{l}\text { The municipality develops possible scenarios for the crisis before it occurs and what can } \\
\text { do in the educational and media sectors }\end{array}$ & 4.514 & 0.547 & High \\
\hline 4 & $\begin{array}{l}\text { The municipality conducts research and studies to uncover problems in the surrounding } \\
\text { environment }\end{array}$ & 4.495 & 0.504 & High \\
\hline 3 & Workers affected by the crisis interviewed to investigate the crisis impact on them & 4.476 & 0.421 & High \\
\hline 2 & The municipality monitors everything that is published or broadcast on the crisis & 4.457 & 0.415 & High \\
\hline 6 & The municipality's performance evaluated according to its response to the crisis & 4.400 & 0.408 & High \\
\hline 7 & $\begin{array}{l}\text { The municipality conducts research and studies to find out the effects of the crisis on } \\
\text { citizens }\end{array}$ & 4.400 & 0.384 & High \\
\hline 9 & The municipality is concerned with the time factor when crises occur & 4.380 & 0.353 & High \\
\hline 10 & The municipality adopts modern means of communication when crises occur & 4.362 & 0.325 & High \\
\hline 8 & The municipality holds conferences and seminars about crisis management & 4.340 & 0.304 & High \\
\hline The variable as a whole & 4.478 & 0.65 & High \\
\hline
\end{tabular}

Source: Researchers 
Table 8. Arithmetic Means and Standard Deviations of the Items of the questionnaire related to media discerningly ordered according to their importance

\begin{tabular}{|c|c|c|c|c|}
\hline No. & Items & Mean & S.D. & Importance \\
\hline 1 & Citizens are provided with real information to reduce the spread of the crisis & 4.470 & 0.589 & High \\
\hline 3 & The municipality allocates a spokesperson for it & 4.390 & 0.686 & High \\
\hline 4 & Information messages sent to citizens & 4.390 & 0.672 & High \\
\hline 2 & The facts presented in a balanced media style & 4.270 & 0.624 & High \\
\hline 5 & The statements prepared before they made & 4.170 & 0.612 & High \\
\hline 6 & Citizens are kept informed & 4.170 & 0.700 & High \\
\hline 7 & The municipality develops a media plan to maintain the positive mental image of the municipality & 4.050 & 0.752 & High \\
\hline 9 & The municipality is concerned with those affected by the crisis & 4.042 & 0.732 & High \\
\hline 10 & Media plans address the post-crisis efforts of the municipality & 4.036 & 0.710 & High \\
\hline 8 & Diversification made in the media used (visual, audio, and print) throughout the crisis stages & 4.031 & 0.675 & High \\
\hline \multicolumn{2}{|c|}{ The variable as a whole } & 4.273 & 0.765 & High \\
\hline
\end{tabular}

Table 9. Arithmetic Means and Standard Deviations of the Items of the questionnaire related to Crisis Management discerningly ordered according to their importance

\begin{tabular}{|l|l|c|c|c|}
\hline No. & Items & Mean & S.D. & Importance \\
\hline 1 & $\begin{array}{l}\text { There is an appropriate operating room within the municipality equipped with modern technologies } \\
\text { to deal with the crisis's causes and the crisis's damages. }\end{array}$ & 4.44 & 0.603 & High \\
\hline 5 & The crisis is controlled when it occurs, limiting its spread and its continuation within a short period & 4.41 & 0.615 & High \\
\hline 2 & $\begin{array}{l}\text { The adequacy and effectiveness of past crisis management plans and programs are evaluated to } \\
\text { improving them to deal with future crises. }\end{array}$ & 4.34 & 0.586 & High \\
\hline 8 & The municipality provides adequate training programs in the field of crisis management. & 4.33 & 0.645 & High \\
\hline 6 & $\begin{array}{l}\text { The municipality holds regular meetings and conducts virtual tests to deal with possible crises in } \\
\text { the municipality in which it works }\end{array}$ & 4.32 & 0.658 & High \\
\hline 3 & $\begin{array}{l}\text { There are comparisons to plans, practices, and decisions in dealing with similar crises and other } \\
\text { organizations to benefit from these lessons. }\end{array}$ & 4.31 & 0.609 & High \\
\hline 7 & $\begin{array}{l}\text { The municipality is forming different and multiple teams to solve many potential crises. } \\
\text { Senior management provides material and moral support to the team that diagnoses and plans for } \\
\text { potential crises. }\end{array}$ & 4.38 & 0.625 & High \\
\hline 9 & $\begin{array}{l}\text { The municipality is interested in collecting and discovering signs of imbalance that may indicate a } \\
\text { crisis. }\end{array}$ & 4.29 & 0.577 & High \\
\hline 10 & $\begin{array}{l}\text { The internal and external work environment thoroughly and frequently scanned to make out the } \\
\text { potential crisis. indicators }\end{array}$ & 4.18 & 0.597 & High \\
\hline The variable as a whole & 4.341 & 0.645 & High \\
\hline
\end{tabular}

Table 10. Testing impact Results of Public Relations on Crisis Management

\begin{tabular}{|l|c|c|c|c|}
\hline $\mathrm{R}$ & Adjusted $\mathrm{R}^{2}$ & $\mathrm{~F}$ & Sig. & Result \\
\hline 0.407 & 0.158 & 40.911 & 0.000 & Rejected \\
\hline
\end{tabular}

The impact statistically significant when $\alpha \leq 0.05$

Source: Researchers

\subsection{Second Hypothesis}

H02: Media has no statistically significant impact on Crisis management in Greater Salt Municipality $(\propto \leq 0.05)$.
Table 11 Testing the impact Results of Media on Crisis Management

\begin{tabular}{|c|c|c|c|c|}
\hline $\mathbf{R}$ & Adjusted $\mathbf{R}^{2}$ & $\mathbf{F}$ & Sig. & Result \\
\hline 0.422 & 0.147 & 45.402 & 0.002 & Rejected \\
\hline
\end{tabular}

The impact statistically significant when $\alpha \leq 0.05$

Source: Researchers 
Table 12. Results of the combined impact of the Department of Public Relations and Media on crisis management

\begin{tabular}{|c|c|c|c|c|c|c|c|c|c|}
\hline \multirow[b]{2}{*}{ 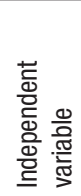 } & \multicolumn{2}{|c|}{ Model Summary } & \multicolumn{2}{|c|}{ ANOVA } & \multicolumn{5}{|c|}{ Coefficients } \\
\hline & $\mathrm{R}$ & $\mathrm{R}^{2}$ & $\mathrm{~F}$ & Sig. & Item & $B$ & Standard Error & $T$ & Sig. \\
\hline \multirow{2}{*}{ 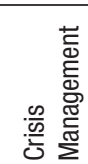 } & \multirow{2}{*}{$\begin{array}{l}0 \\
\text { 茴 } \\
0\end{array}$} & \multirow{2}{*}{ ş } & \multirow{2}{*}{\begin{tabular}{|l}
$\infty$ \\
0 \\
0 \\
$\dot{b}$ \\
1
\end{tabular}} & \multirow{2}{*}{ : } & $\begin{array}{l}\text { Public Relations } \\
\text { Dept. }\end{array}$ & 0.133 & 0.064 & 2.078 & 0.045 \\
\hline & & & & & Media & 0.024 & 0.062 & 0.393 & 0.694 \\
\hline
\end{tabular}

The impact is statistically significant when $\alpha \leq 0.05$

Source: Researchers

In turn, to test the hypothesis, simple linear regression was used, and the results of this test shown in Table 11.

The $\mathrm{F}$ value equals 45.402 , which is a statistically significant value, indicating that the null hypothesis was rejected. The alternative hypothesis accepted, which means Media statistically has a considerable impact on crisis management in the Greater Municipality of Salt reinforced by the explanatory value of $\mathrm{R} 2$ that equals 0.158 .

To test the primary hypothesis, multiple linear regression analysis used the flowing outcome shown in Table 12.

Table (12) results illustrate that the correlation coefficient $\mathrm{R}=0.650$ points out the connection between independent and dependent variables. Thus the impact of the independent variables as a Public Relations and Media on the dependent variable Crisis Management is statistically significant, where the calculated value of $\mathrm{F}$ is 54.068 , at the level of significance $(0.000)$ is lesser than 0.05 , it comes into view that the determination coefficient value of $\mathrm{R}^{2}=0.431$ which indicates $43.1 \%$ of the variance in (crisis management be explained through combined variation in Public Relations Department and Media.

The coefficients Table has shown that the value of B in the Department of Public Relations reached 0.133 the $\mathrm{T}$ value of 2.078 is at a level of significance (0.045), which indicates that dimension Impact is significant. The B value of media reached 0.024 , that T's value is 0.393 , with a considerable level of significance is
0.694, indicates that this dimension's impact is not significant.

Base on the above, the main null hypothesis was rejected, and the alternative hypothesis was accepted. However, "There is a statistically significant effect at the level of significance $(\alpha \leq 0.5)$ of the Department of Public Relations and Media on Crisis Management in Greater Municipality of salt.

\section{Conclusion}

Based on the results reached, in addition to reviewing the previous literature related to the study subject, the study sample is aware of the importance of public relations management in Greater Salt Municipality and its effectiveness in setting the necessary training programs and conducting research to uncover the environmental problems and develop possible scenarios for the crisis before it occurs. Also, media has an influential role in maintaining media plans to preserve the positive image that can send media messages to citizens through prompt and appropriate information. Besides, the Greater Salt Municipality adopts a scientific methodology in dealing with crises through holding periodic meetings and virtual experiments to deal with potential crises and providing training programs in the field of crisis management, in addition to its ability to limit the spread of crises. Thus, the Public Relations Department has a significant effect on crisis management, and media has a significant impact on crisis management. Besides, extra consideration on previous crises helps the policymakers in the endowment of material and moral support to the public relations management 
team in future crises. Besides, holding conferences and seminars on crisis diversification and using modern communication technology is compulsory as soon as crises occur and provide citizens with information instantly. Also, to reduce the aggravation of crises and their secondary effects, employing crisis management experts is necessary.

\section{References}

Abu-Tayeh, S. N., \& Mustafa, M. H. (2018). Tourism crisis management in Jordan: An Overview. Advances in Social Sciences Research Journal. 5(2). https://doi. org/10.14738/assrj.52.4210

Ahmed, A. F. A. (2018). Media and crisis management. 1st Edition, Cairo, Dar Al-Alamia for Publishing and Distribution, p. 94.

Al-Bazzaz, H. (2001). Crisis management between boiling and transformation points. Beirut: University Foundation for Studies, Publishing and Distribution.

Al-Dulaimi, A. M. (2011). Introduction to public relations. Dar Al-Thaqafa for Publishing and Distribution, Jordan.

Al-Hassoun, F. A. (2012). The role of public relations in economic crisis management: An empirical study on the volatility of the Saudi capital market. Master Thesis. Cairo University.

Al-Jarallah, M. A. S. (2010). Efforts of public relations departments in the face of crises: A field study on a sample of private sector companies in the Kingdom of Saudi Arabia. (Master Thesis), Imam Muhammad bin Saud Islamic University.

Al-Jenaibi, B. (2015). E-collaboration, public relations and crises management in UAE organizations. International Journal of E-Collaboration, 11(3), 10-28. https://doi. org/10.4018/ijec.2015070102

Al-Lawzi, M. (2010). The foundations of public relations: Concepts and foundations. Zamzam Publishers and Distributors, Amman-Jordan.

Al-Muhammadi, S. A. R. (2018). Strategic management: Formulation, alternatives, tests, and implementation. 1st Edition, Amman, Dar Al-Yazouri Publishing and Distribution, pp. 33-39.

Almahraj, Y. (2017). The profession of public relations in Saudi Arabia: A socio-cultural perspective. PhD Thesis, Queen Margaret University.

Al-Naji, F. A. (2012). The impact of modern crisis management strategies on marketing performance: A field study on human pharmaceutical industrial companies in Greater Amman City. (Master Thesis), Middle East University.

Al-Qahtani, S. (2004). The role of public relations management in dealing with crises and disasters: An applied study on public relations management in civil defense. (Master Thesis), Riyadh, Naif University for Security Sciences.

Al-Rubaie, F. A. (2010). Public relations programs and the strategy of building and enhancing the foundation's reputation. Scientific Researcher Magazine, 8, 167-193.

Al-Shami S. A., \& Mohammed T. A.(2009). Effect of replacement of barley grains by wasted bread crumbs or rejected dates on growth performance and growing rabbits carcass traits. Pakistan Journal of Nutrition, 8(5), 635-641. https://doi.org/10.3923/pjn.2009.635.641

Al-Saeedi Y. O. A. (2013). The role of public relations in achieving job satisfaction for employees in the Kuwaiti Al-Rai and Kuwait times newspapers. (Master Thesis), Middle East University.

Al-Sawafi I. M.(2018). Crisis management approach - goals strategies. 1st edition, Amman, Dar Degla, pp. 139.

Alzahrani, F. (2016). The role of public relations in organizational crisis management. International Journal of Scientific \& Engineering Research, 7(1), 1085-1086.

APFM.(2015). The role of the media in flood management. Available from: http://www.floodmanagement.info/ publications/tools/Tool_22_The_Role_of_the_Media in_Flood_Management.pdf

Arpan, L., \& Pompper, D. (2003). Stormy weather: Testing stealing thunder as a crises communication flow between organizations and journalists. Public Relations Review, 29(2), 291-308. https://doi.org/10.1016/ S0363-8111(03)00043-2

Anand, D., \& Hosseini, S. B. (2016). Online consumer protection- present realities, pressing problems and future prospects. EPRA International Journal of Economic and Business Review, 4(5).

Christophe, R. (2007). Is crises management conley management of exceptions. Journal of Contingencies and Crises Management, 15(2), 105-114. https://doi. org/10.1111/j.1468-5973.2007.00507.x

Christine M. P., \& Mitroff, I. I. (1993). A framework for crisis management, Academy of Management. 7(1), 48-59. https://doi.org/10.5465/ame.1993.9409142058

Daraghmeh, R. A. A. (2011). The role of public relations departments in palestinian universities in building relationships with the student community: A comparative survey study. (PhD Thesis), The Hague University, The Netherlands. 
Das, A. (2009). Political crisis and media's role towards conflict resolution: A study in Indian context. 7th AMSAR Conference on Roles of Media during Political Crisis, pp. $1-17$.

Fall, L. T. (2004). The increasing role of public relations as a crisis management function: An empirical examination of communication strategizing efforts among destination organization managers in the wake of 11th September 2001. Journal of Vacation Marketing, 10(3), 238-252. https://doi.org/10.1177/135676670401000304

Fazli, S., \& Farooq, A. (2018). Organizational effectiveness of private enterprises and diversification in the gulf countries, Economic Diversification in the Gulf Region, 1(1), 137-162) https://doi.org/10.1007/978-981-105783-0_7

Farooq, A., \& Dinney, M. (2009). Impact of authority decentralization on organizational commitment: An empirical study of development projects in Kerala, Management and Labor Studies, 34(1), 27-42. https:// doi.org/10.1177/0258042X0903400102

Ghassabi, F., \& Zare, F. F. (2015). The role of media in crisis management: A case study of Azerbaijan earthquake. International Journal of Health-System and Disaster Management, 3(2), 95-102.

Hawamdeh, N. (2003). Crisis management from the perspective of the case study approach: The Jordanian Cooperative Organization: An analytical applied study. Damascus University Journal for Economic and Legal Sciences, 19(1).

Hosseini, S. B., \& Farooq, A. (2019). A review on tourism industry and hospitalities in U.K and India - with brief look on role of human resource management strategies and UNWTO Frameworks, Restaurant Business, 118(9), 408-424. https://doi.org/10.26643/rb.v118i9.8616

Hosseini. S. B. (2019). Rights to work's challenges for refugees, UNHCR and ILO responses, with special references to refugees and asylum seekers from wartorn in the Middle East. EPRA International Journal of Economic and Business Review, 7(10), 5-13.

Holly M. H. (2008). Crisis management in higher education: What have we learned from Virginia tech? Advances in Developing Human Resources, 12(5), 552-572. https:// doi.org/10.1177/1523422310394433

Jafar, K. (2009). Social networks and labour market: The experience of Malayalee workers in Bangalore, India. MPRA Paper, University Library of Munich, Germany.
Jamal, R. M., \& Ayyad, K. M. (2017). Public Relations Department: The Strategic Entry, Dar Al-Maria Al Libnani, pp. 73.

Klepka, R. (2019). The role of media in informing and acting for the sake of national security. State security in the contemporary world. 1st edit, Wydawnictwo Drukarnia Styl Anna Durham, pp. 251-263.

Masoumi, G., \& Noyani, A. (2019). The role of media in community resilience of disaster. Academics World 145th International Conference, pp. 16-18.

Mat, T. S. N., \& Kaur, K. (2017). Exploratory study of a crisis commander's perspectives on the role and value of public relations in crisis management. SHS Web of Conferences, 33, 00047. https://doi.org/10.1051/shsconf/20173300047

MH, D. K., Hosseini, S. B., Farooq, A., Arab, H., \& Takroosta, A. (2019). A strategic review on economic dispatch distribution and environmental considerations. Restaurant Business, 118(12), 166176. doi.org/10.26643/rb.v118i12.13211 https://doi. org/10.26643/rb.v118i12.13211

MH, D. K.; Hosseini, S. B., Farooq, A., Azadeh, S. K., \& Delfin, D. M. (2019). A study on causal relationship between sugar beet supply and sugar price - sustainability issues and opportunities. GIS Business, 14(6), 445-462. https://doi.org/10.26643/gis.v14i6.13581

Qwaider, A. D. M., Hosseini, S. B., \& Farooq, A. (2019). Organizational agility and HRM practices: Theoretical framework and perspective. Restaurant Business, 118(12), 177-194. https://doi.org/10.26643/ rb.v118i12.13214

Sawalha, I. H. S., Jraisat, L. E., \& Al-Qudah, K. A. M. (2013). Crisis and disaster management in Jordanian hotels: Practices and cultural considerations. Disaster Prevention and Management: An International Journal, 22(3), 210-228. https://doi.org/10.1108/DPM-09-20120101

Sekaran. U. (2003). Research methods for business: A skill building approach. 4th edition. John Wiley \&Sons, Inc.

Smith, J. L. (2007). When it hits the fan : A public relations' practitioners' Guide to Crisis Communication. Master Thesis, Georgia State University.

Zidan, M. (2003). Evaluating Performance and Confronting Crises. Cairo, The Nile Arab Group. 